\title{
A Polymer Coated Cicaprost-Eluting Stent Increases Neointima Formation and Impairs Vessel Function in the Rabbit Iliac Artery
}

\author{
Christopher McCormick ${ }^{1}$ Robert L. Jones ${ }^{2}$, Roger M. Wadsworth ${ }^{2}$, Alexander B. Mullen², \\ Simon Kennedy ${ }^{*}$ \\ ${ }^{1}$ Biomedical Engineering Department, University of Strathclyde, Glasgow, UK \\ ${ }^{2}$ Strathclyde Institute of Pharmacy and Biomedical Sciences, University of Strathclyde, Glasgow, UK \\ ${ }^{3}$ Institute of Cardiovascular and Medical Sciences, University of Glasgow, Glasgow, UK \\ Email: *simon.kennedy@glasgow.ac.uk
}

Received 1 June 2016; accepted 20 June 2016; published 24 June 2016

Copyright (C) 2016 by authors and Scientific Research Publishing Inc.

This work is licensed under the Creative Commons Attribution International License (CC BY). http://creativecommons.org/licenses/by/4.0/

c) (i) Open Access

\begin{abstract}
Drug-eluting stents have been successful in reducing in-stent restenosis but are not suitable for all lesion types and have been implicated in causing late stent thrombosis due to incomplete regeneration of the endothelial cell layer. In this study we implanted stents coated with cicaprost, a prostacyclin analogue with a long plasma half-life and antiproliferative effects on vascular smooth muscle cells, into the iliac arteries of rabbits. At 28-day follow-up we compared neointima formation within the stented vessels and vascular function in adjacent vessels, to assess if cicaprost could reduce restenosis without impairing vessel function. Arteries implanted with cicaprost eluting stents had significantly more neointima compared to bare metal stents. In adjacent segments of artery, endothelium-dependent relaxation was impaired by the cicaprost-eluting stent but vasodilation to an endothelium-independent vasodilator was maintained. We conclude that the presence of the polymer and sub-optimal release of cicaprost from the stent may be responsible for the increased neointma and impaired functional recovery of the endothelium observed. Further experiments should be aimed at optimising release of cicaprost and exploring different stent polymer coatings.
\end{abstract}

\section{Keywords}

Cicaprost, Neointima, Iliac Artery, Endothelium, Drug-Eluting Stent

\footnotetext{
${ }^{*}$ Corresponding author.
}

How to cite this paper: McCormick, C., Jones, R.L., Wadsworth, R.M., Mullen, A.B. and Kennedy, S. (2016) A Polymer Coated Cicaprost-Eluting StentIncreases Neointima Formation and Impairs Vessel Function in the Rabbit Iliac Artery. Pharmacology \& Pharmacy, 7, 226-235. http://dx.doi.org/10.4236/pp.2016.76029 


\section{Introduction}

Drug-eluting stents have substantially reduced restenosis rates compared to bare metal stents [1]. They have overtaken Coronary Artery Bypass Graft (CABG) surgery as the main revascularisation method used for treatment of advanced coronary artery disease. However, there is evidence that they do not perform as well as CABG in some cases, most notably in those patients with more than one diseased coronary artery [2] and/or with existing co-morbidities [3]. Moreover, concerns remain around delayed healing and prolonged thrombosis risk [4], and although restenosis now occurs less frequently, it remains a clinical problem [5]. In addition, long term endothelial dysfunction in artery sections adjacent to implanted DES has also been reported [6]-[9]. Consequently, there is still a need to develop improved drug-eluting stents which retain the low restenosis rates of the current stents but do not impair endothelial recovery and compromise vessel function in the surrounding, non-stented region.

In-Stent Restenosis (ISR) is a multifactorial cascade of events, where the outcome is the development of a neointima consisting of smooth muscle cells and extracellular matrix [10]. Balloon expansion and stent placement damage the endothelium leading to platelet adhesion, activation, and the generation of a thrombus [11]. The surface of the stent also causes activation of circulating neutrophils and macrophages within arterial tissue [12]. The release of cytokines and growth factors by transmigrated inflammatory cells activates smooth muscle cells and upregulation of matrix metalloproteinases leads to smooth muscle cell migration from the medial layer to the intimal layer. As new extracellular matrix is laid-down, a neointimal layer is formed which reduces lumen size [12].

Prostacyclin $\left(\mathrm{PGI}_{2}\right)$ analogues are known to inhibit platelet activation [13] and smooth muscle cell proliferation in a variety of species, including humans [14] [15]. Although the role of endogenous $\mathrm{PGI}_{2}$ in modulating inflammatory responses is complex [16], there is evidence that its analogues can inhibit leukocyte adhesion to endothelial cells [17]. Since these are two pivotal events in neointima formation, $\mathrm{PGI}_{2}$ analogues may represent promising candidates for incorporation within a novel DES. Indeed, the $\mathrm{PGI}_{2}$ analogue iloprost, in combination with the thrombin inhibitor hirudin, reduced neointima formation in the pig coronary artery [18]. However, the effect of iloprost alone was not reported, and no study to date has examined the effect of any locally delivered $\mathrm{PGI}_{2}$ analogue alone on neointima formation following stent-induced injury. In a previous study by our group we examined the vascular effects of various $\mathrm{PGI}_{2}$ analogues [19]. It was found that although AFP-07 was a more potent vasodilator than cicaprost, it induced an $\mathrm{EP}_{3}$ receptor-mediated contraction in the rabbit iliac artery at high concentrations. Both compounds had a moderate anti-proliferative effect on rabbit smooth muscle cells, which in the case of cicaprost was not modified by an EP receptor antagonist. Thus cicaprost, with its superior selectivity for IP receptors [20], may represent the more promising candidate drug for incorporation within a novel drug-eluting stent.

Implantation of some drug-eluting stents can affect vasomotion in upstream and downstream areas of the vessel [6]-[9] and this may be associated with impaired endothelial regrowth. Although abnormal vasomotion would be considered undesirable, with potential to impair tissue perfusion distal to the stented region, it is rarely investigated during preclinical studies on novel drug-eluting stents. In this study we have implanted novel cicaprost-eluting stents in the iliac arteries of experimental rabbits. At 28-day follow-up we compared neointima formation as well as vascular function in adjacent vessels areas to assess if cicaprost could reduce restenosis without impairing vessel function.

\section{Methods}

\subsection{Stent Coating Development}

Poly (L-lactide) (PLLA, $150 \mathrm{kDa}$ ) was used as a polymer matrix to provide controlled release of cicaprost from the stent surface. A $1 \mathrm{ml}$ coating solution of 5\% (w/v) PLLA: cicaprost (98: 2) was prepared in chloroform. The formulation was selected to deliver cicaprost at a therapeutic dose, identified from our in vitro smooth muscle cell proliferation studies [19], and was based on a similar previously reported methodology that had achieved sustained release of iloprost and hirudin from a polymer coated stent [18]. Balloon mounted stents were immersed in this solution via a manual dipping process. Immersion times were approximately 1 second per coating. Two coatings were applied to each stent in this way, providing an average coating mass of approximately 900 $\mu \mathrm{g} / \mathrm{stent}$ (based on measurements from three separate stents with an average length of $16 \mathrm{~mm}$ ). A minimum of 12 hours was allowed for solvent evaporation to take place prior to stent implantation in vivo. 


\subsection{In Vivo Stent Implantation}

Animal care and all procedures conformed to the requirements of the U.K. Animals (Scientific Procedures) Act 1986. The rabbit iliac artery model of stent injury has been previously characterised [21], and has been shown to have a range of prostanoid receptors, relevant to the assessment of $\mathrm{PGI}_{2}$ mediated effects [19]. Male New Zealand White rabbits (2.3 - 2.5 kg; 11 - 13 weeks of age, sourced from Harlan; Cambridgeshire, UK) were premedicated with $1.2 \mathrm{ml}$ i.m. of Hypnorm ${ }^{\circledR}$ (fluanisone/fentanyl citrate mixture), $100 \mathrm{mg}$ i.m. of ampicillin suspension, and 500 units of heparin i.v. The animals were maintained throughout the procedure on a mixture of $2 \%$ nitrous oxide and $1 \%-1.5 \%$ isoflurane in oxygen. Stents (see Table 1) were introduced through the femoral artery using a 0.014 in. steerable guidewire and implanted in the iliac artery under fluoroscopic guidance. The stent was deployed by inflating the balloon to a pressure sufficient to achieve a 1.1: 1 stent: artery ratio. Pressure was maintained for a period of $30 \mathrm{~s}$, after which the balloon was deflated and withdrawn. The femoral artery was permanently ligated and the wound closed and sutured. All animals received oral aspirin (35 mg) daily commencing one day before surgery, and for four days post-surgery.

\subsection{Rabbit Artery Removal and Processing}

Rabbits were euthanized after 28 days by overdose of sodium pentobarbital. The 28-day end point is in accordance with best practice and our previous experience with this model, where we have observed marked neointima formation at this time point [21]. Iliac arteries were immediately dissected out, with sections $3 \mathrm{~mm}$ proximal and distal to the implanted stent being retained in Krebs' solution for functional studies. Stented artery sections were fixed in resin according to a previously published methodology [22]. Briefly, sections were placed in formal saline solution (24 hrs), followed by acetone (24 hrs) and infiltration solution (Technovit 8100, $24 \mathrm{hrs),}$ before being fixed in hardening solution for a minimum period of 24 hours at $4^{\circ} \mathrm{C}$. Hardened sections were cut using a diamond saw and polished using a rotary grinder (Buehler Isomet and Metaserv). Sections were stained with haematoxylin and eosin and an average of three sections from each artery (from proximal, middle, and distal sections) were prepared for planimetric analysis.

\subsection{Histological Examination and Analysis}

Stented artery sections were digitally photographed and the areas of key artery structures quantified using commercially available software (Image-Pro express). The areas bounded by the lumen, internal and external elastic laminae (IEL and EEL respectively), and neointima were quantified for each section. Percent vessel stenosis was calculated as follows:

$\%$ stenosis $=100 \times(1-(1$ umen area/IEL area $))$.

Stent injury scores were calculated according to the method proposed by Gunn et al., where injury scores range from 0 to 4 depending on the degree of vessel stretch, and extent of damage to the internal and external elastic laminae [23]. Specifically, this scale ranges from no injury (0), through to stretch (1 or 2, depending on the angle of IEL deformation) and deep injury (3 (IEL ruptured) or 4 (EEL ruptured)). An individual injury score was assigned to each visible stent strut, with the average value of all stent struts being calculated for an individual artery section. All interpretation of strut injury scores and histological staining was performed in a blinded fashion.

\subsection{Vessel Function Study}

Isometric function studies were used to assess the effect of stent placement and local cicaprost elution on the function of nearby vasculature. 2 - $3 \mathrm{~mm}$ artery rings were suspended between two intraluminal metal wires, one fixed with the other connected to an isometric force transducer. Following the establishment of consistent

\begin{tabular}{cccc}
\multicolumn{4}{l}{ Table 1. Stent platform and dimensions used for the two study groups. } \\
\hline Study Group & Stent Platform & Diameter $(\mathrm{mm})$ & Length $(\mathrm{mm})$ \\
\hline Bare metal group $(\mathrm{n}=4)$ & Liberte & 2.5 & $8-16$ \\
\hline Cicaprost Stent Group $(\mathrm{n}=5)$ & Mini Vision & $2.25-2.5$ & $18-23$ \\
\hline
\end{tabular}


responses to two repeat doses of $\mathrm{KCl}(40 \mathrm{mM})$, artery rings were exposed to cumulative additions of phenylephrine $(10 \mathrm{nM}-10 \mu \mathrm{M})$. Endothelium-dependent responses were assessed by cumulative addition of carbachol (10 $\mathrm{nM}$ - $10 \mu \mathrm{M})$, following pre-contraction to phenylephrine $(0.3 \mu \mathrm{M})$. A single dose of the endothelium-indepen- dent vasodilator SIN-1 $(2 \mu \mathrm{M})$ was added to test smooth muscle responses at the end of each protocol.

All data are presented as the mean \pm one standard error of the mean. In artery function studies, statistically significant differences between curves were calculated using a two-way ANOVA using Graphpad Prism V4.0 program. Where appropriate, best fit curves were applied to data sets using a linear regression sigmoidal dose response curve using Graphpad Prism. An unpaired Student's t-test was used to compare in vivo data sets. In all cases differences were considered significant when the p value was less than 0.05 .

\section{Results}

\subsection{In Vivo Efficacy Study}

The stent injury score was significantly greater in the cicaprost coated group compared to the bare metal control stents (Figure 1). Both the neointimal area and percentage stenosis were also found to be significantly greater in the cicaprost coated group.

Figure 2 illustrates representative photomicrographs of stented artery sections. The vessel response to stent placement is characterised by moderate neointima formation in all bare metal stents (panels a, c, d and e), with greater levels of neointima found in the cicaprost group (b and f). In the cicaprost group, neointimal tissue growth of similar histological appearance to the tissue growth observed in the bare metal stent group was found in three out of the five stented vessels (panel b). In these three vessels, the neointimal tissue encroaches into the lumen (panel f). In the remaining two vessels in the cicaprost group, there was a distinct response with near complete occlusion of the vessel.

\subsection{Vessel Function Study}

Figure 3 details the results of the vessel function study. Bare metal stents had no significant effect on contractile (panel a) or endothelium-dependant relaxation (panel b) in distal sections compared to proximal sections. Cicaprost-coated stents significantly reduced contractile function in distal vessel sections compared to bare metal controls (panel e), with no difference being observed proximal to the stent (c). Endothelium-dependent relaxation was reduced both proximal (panel d) and distal to the cicaprost stent (f) compared to the bare metal stent, although the distal effect just failed to reach significance $(\mathrm{p}=0.0549)$. SIN-1 $(2 \mu \mathrm{M})$ produced complete relaxation in all vessels.

\section{Discussion}

It was our hypothesis that $\mathrm{PGI}_{2}$ analogues may represent promising compounds for use in drug-eluting stents by virtue of their unique biological profile; which includes inhibition of platelet activation, and smooth muscle cell
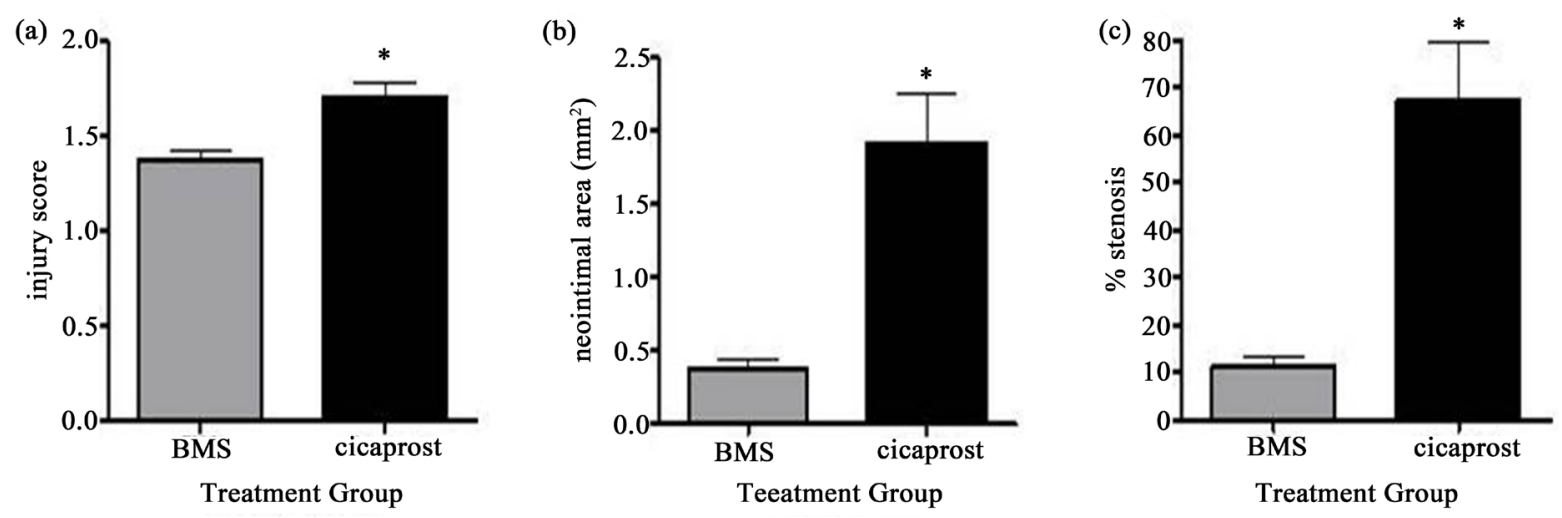

Figure 1. Stent injury score, percent stenosis and neointimal area in the two treatment groups observed at 28 days following stent placement in the rabbit iliac artery. ${ }^{*} \mathrm{p}<0.05$ for cicaprost stent $(\mathrm{n}=5)$ versus bare metal stent $(\mathrm{BMS})$ control $(\mathrm{n}=4)$. 

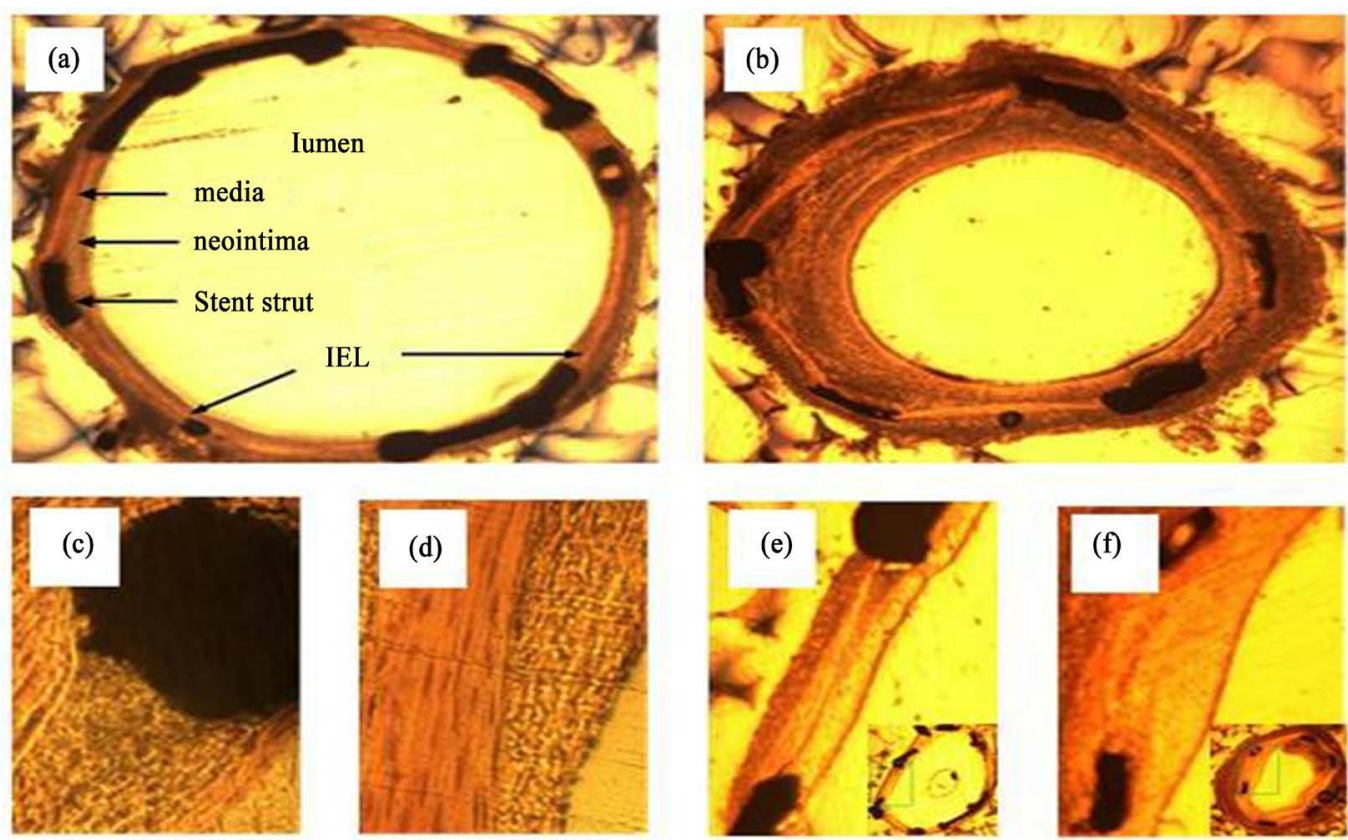

Figure 2. Histological specimens stained with haematoxylin and eosin, highlighting typical results of in vivo stent placement in bare metal control (a) and cicaprost coated group (b). Small areas of neointimal tissue are evident around (c) and between stent struts ( $\mathrm{d}$ and e) in the bare metal stent group. Classical neointima encroached into lumen within the cicaprost stent group (f). Panel a indicates the location of the key features, including the media, neointima, stent strut, the internal elastic lamina (IEL) and the lumen. In panels c-f, the lumen lies on the right hand side of the image. Magnification levels were x20 (a and b) and x 400 (c and d). Panels e and f are sections taken from a whole artery image obtained at x20 (shown as an insert) and subsequently resized to highlight key features of the original image.

proliferation. The present study is the first to report the effect of any $\mathrm{PGI}_{2}$ analogue alone, delivered locally from the stent surface, on neointima formation.

At 28 days, we found that the neointimal area was significantly greater in vessels treated with a cicaprost-eluting stent compared to control stents. This is in contrast to what may have been predicted from in vitro studies, which have broadly demonstrated inhibitory effects on smooth muscle cell proliferation [14] [15]. In vivo, although some negative results have been reported [24], $\mathrm{PGI}_{2}$ analogues have generally been shown to reduce restenosis in pig and rabbit models of balloon angioplasty without stent implantation [25] [26]. Whilst differences exist, there is significant similarity in the mechanisms behind the neointima formation in balloon angioplasty and stenting. It may therefore have been expected that the generally positive results observed in angioplasty studies would have been maintained in the present study. Similarly, a stent releasing iloprost and hirudin in combination reduced neointima formation in the pig coronary artery [18]. There are several possible reasons for this apparent discrepancy in outcomes.

Despite using a constant stent to vessel ratio of 1.1: 1 throughout the study, a significant difference was observed in the stent injury scores between the bare metal control and the cicaprost coated stent group. The injury scores for both groups of $1.38 \pm 0.04$ (BMS) and $1.71 \pm 0.08$ (cicaprost) are comparable to the value of 1.74 reported in the pig coronary artery by Gunn et al [23] using the same scoring technique. It is well established that the extent of injury is a significant determinant of the subsequent degree of neointima formation observed [27]. A higher level of injury may therefore represent one factor responsible for the increased neointimal response observed in the cicaprost group.

It is known that cicaprost has weak activity at prostanoid $\mathrm{EP}_{1}$ and $\mathrm{EP}_{3}$ receptors [20], and whilst we have previously demonstrated that cicaprost is selective for the IP receptor up to $1 \mu \mathrm{M}$ in vitro [19], we have also observed that excess $\mathrm{PGI}_{2}$ analogue concentrations may activate $\mathrm{EP}_{1}$ and $\mathrm{EP}_{3}$ receptors, leading to vasoconstriction. Blindt has shown that $\mathrm{EP}_{3}$ receptor activation can lead to increased smooth muscle cell migration [28]. Therefore, high local cicaprost concentrations in the present study may have produced unwanted arterial constriction 
(a)

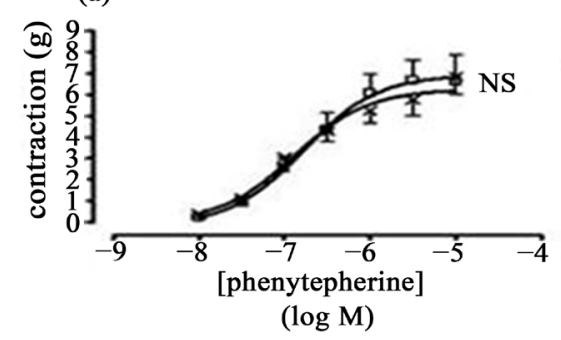

(c)

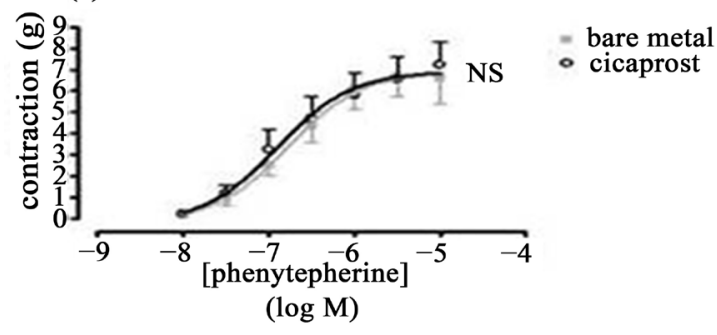

(e)

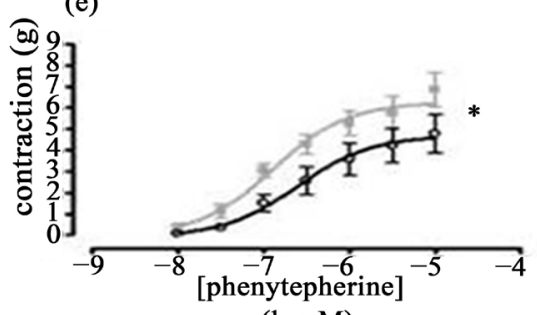

$(\log \mathrm{M})$ o proximal

$\times$ distal
- bare metal - cicaprost

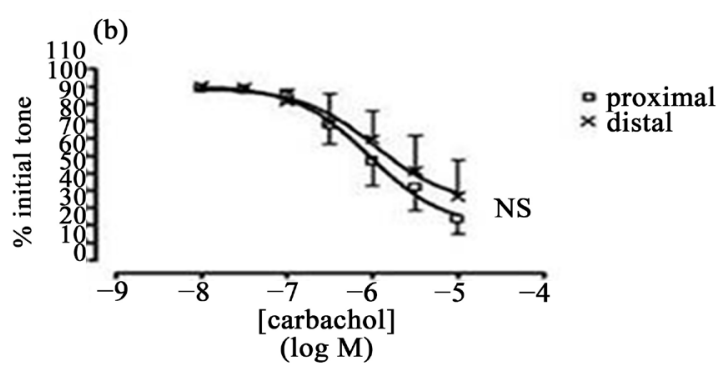

(d)

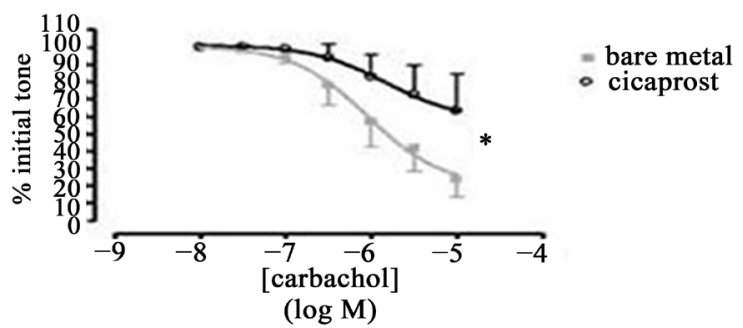

(f)

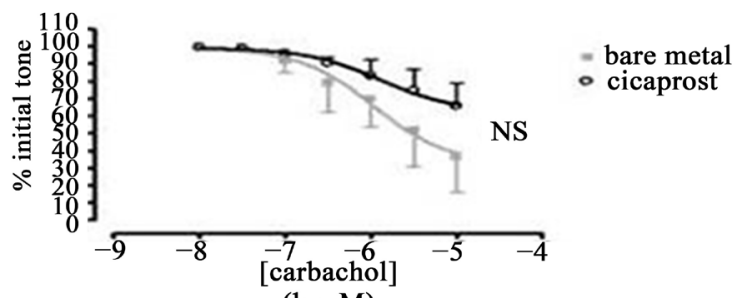

Figure 3. Contractile function and endothelium-dependent relaxation in rabbit iliac artery sections proximal and distal to implanted stents. Stents were in situ for 28 days before arteries were removed for functional studies. Concentration-response curves to phenylephrine (a) and carbachol (b) did not differ in artery sections proximal and distal to bare metal stents. Concentration-response curves to phenylephrine in artery sections proximal (c), and distal (e) and to carbachol proximal (d) and distal (f) to the stent revealed that cicaprost-eluting stents affected vessel function. $n=4-5 ;{ }^{*} p<0.05$ vs. bare metal stent.

and stimulated increased smooth muscle cell migration. However, the extensive variety of prostanoid receptors and functions make interpretation of the in vivo data complex. In mice deficient in the prostanoid IP receptor there was increased thrombosis and increased inflammatory responses as evidenced by increased microvascular permeability [29]. The delivery of cicaprost may be sufficient to cause a significant disruption of the prostacyclin-thromboxane balance which is important in maintaining vascular haemostasis [30]. However, without data on the tissue concentration of cicaprost and how this varies over the 28 day follow-up it is difficult to understand why cicaprost had such a negative effect on neointima formation.

Our preliminary drug release studies using iloprost as a model $\mathrm{PGI}_{2}$ analogue demonstrated that $50 \%$ of the total iloprost released during the 14 day measuring period occurred within the first 24 hours (data not shown). Based on this, in vivocicaprost release is likely to also occur rapidly, inhibiting the initial platelet aggregation at the site of arterial injury, and in so doing disrupt the normal vessel healing processes. This scenario may explain the failure to translate the generally positive results observed following balloon injury to stent placement, where the stent serves as a continuous stimulus to inflammation. As cicaprost release tails off, the presence of an unhealed vessel wall and stent may lead to a late platelet response and extensive neointima formation. A similar situation has been observed where platelet depletion for the first 14 days following endothelial denudation in- 
hibited neointima formation, an effect which was reversed when fresh platelets were infused between 14 days and 28 days in the rat carotid artery [31]. Because the concentration of cicaprost in tissue was not measured in vivo, it is not possible to determine whether the effects we observed were due to a toxic drug concentration.

An alternative hypothesis is that the polymer coating was responsible for the dramatic increases in neointima produced by the cicaprost stent. Poly (L-lactide) (PLLA, $150 \mathrm{kDa}$ ) was selected as the drug carrier for a number of reasons, including its reported biocompatibility. Poly (lactide) based polymers have been demonstrated to have minimal effect on restenosis in a number of animal studies [18] [32], whilst a biodegradeable PLLA stent has been shown to be well tolerated in human coronary arteries [33]. However, PLLA (80 kDa) can produce a severe inflammatory neointimal response and vessel occlusion in the pig coronary artery, whereas higher molecular weight PLLA (300 kDa) was well tolerated [34]. It is therefore possible that the polymer induced a greater inflammatory response in the treatment group compared to the bare metal control; however we did not measure this in our study. The change in surface characteristics caused by the polymer may also have had a negative impact on stenosis development. Such characteristics are an important determinant of the vessel reaction, with properties such as high surface energy and roughness being predictors of thrombosis formation [35]. In the present study it was observed that areas of the polymer coating between struts had potential to rupture following stent expansion, and hence decrease the uniformity and surface smoothness of the coating, which could act as a stimulus to increased thrombus formation. Equally, there was an uneven polymer distribution between struts. The deleterious effects of uneven polymer distribution have been highlighted previously [36]. The near complete vessel occlusion and severe disruption of normal arterial structures that we observed in 2 out of 5 cicaprost treated arteries, is consistent with the findings of this previous study [36]. Therefore, deleterious effects due to the PLLA polymer and its non-uniformity across the stent surface cannot be ruled out.

In addition to incomplete endothelialisation, existing drug-eluting stents have been associated with endothelial cell dysfunction in surrounding artery sections [6]-[9]. In our study it was found that in arteries implanted with a bare metal stent, proximal and distal sections produced similar constrictive and relaxation responses. This finding is consistent with observations obtained clinically following bare metal stent placement, where no difference was found in distal artery responses to acetylcholine infusion [7]. Endothelium-dependent relaxation responses to carbachol in the cicaprost group were significantly reduced in proximal sections compared to bare metal controls, with a similar trend observed distally $(\mathrm{p}=0.0549)$. This suggests that the deleterious effect of the cicaprost stent placement on the endothelium may be independent of direction of blood flow, which is in contrast to the findings of Moses et al, 2003 [37]. They demonstrated a reduced neointima formation in distal stented sections compared to proximal stented sections following sirolimus-eluting stent placement, possibly supporting the hypothesis that drug elution tends to occur distal to the stent. However, our results are in agreement with the endothelial dysfunction demonstrated proximal and distal to a paclitaxel eluting stent [7] and this may indicate differences in how eluting drugs are affected by local physiological transport forces within the artery wall. Since there was no difference between endothelium-dependent responses proximal or distal artery tissue in the bare metal stent group, we can attribute this effect to the cicaprost stent itself, rather than an effect of the reduced blood supply due to severe stenosis and possible ischaemia. All artery sections produced complete relaxation following a single dose of SIN-1, suggesting that the medial layer function was unaltered by placement of either stent type.

\section{Conclusion}

This is the first study to report the effects of a novel polymer-coated cicaprost releasing stent. Our data indicate that PLLA-cicaprost coated stents have a deleterious effect on arterial recovery following injury. The high stenosis rate was possibly due to the polymer and a rapid release of cicaprost from the stent may have affected functional recovery of the endothelium in the adjacent artery. However, the precise mechanisms behind the failure of this novel stent remain to be elucidated. Further studies, most notably examining the direct effect of the polymer coating and of different drug loadings, are therefore required.

\section{References}

[1] Babapulle, M.N., Joseph, L., Bélisle, P., Brophy, J.M. and Eisenberg, M.J. (2004) A Hierarchical Bayesian MetaAnalysis of Randomised Clinical Trials of Drug-Eluting Stents. Lancet, 364, 583-591. http://dx.doi.org/10.1016/S0140-6736(04)16850-5 
[2] Serruys, P.W., Morice, M.C., Kappetein, A.P., Colombo, A., Holmes, D.R., Mack, M.J., Stahle, E., Feldman, T.E., van den Brand, M., Bass, E.J., Van Dyck, N., Leadley, K., Dawkins, K.D. and Mohr, F.W. (2009) Percutaneous Coronary Intervention versus Coronary-Artery Bypass Grafting for Severe Coronary Artery Disease. New England Journal of Medicine, 360, 961-972. http://dx.doi.org/10.1056/NEJMoa0804626

[3] Farkouh, M.E., Domanski, M., Sleeper, L.A., Siami, F.S., Dangas, G., Mack, M., Yang, M., Cohen, D.J., Rosenberg, Y., Solomon, S.D., Desai, A.S., Gersh, B.J., Magnuson, E.A., Lansky, A., Boineau, R., Weinberger, J., Ramanathan, K., Sousa, J.E., Rankin, J., Bhargava, B., Buse, J., Hueb, W., Smith, C.R., Muratov, V., Bansilal, S., King, 3rd, S., Bertrand, M. and Fuster, V. (2012) Strategies for Multivessel Revascularization in Patients with Diabetes. New England Journal of Medicine, 367, 2375-2384. http://dx.doi.org/10.1056/NEJMoa1211585

[4] Joner, M., Finn, A.V., Farb, A., Mont, E.K., Kolodgie, F.D., Ladich, E., Kutys, R., Skorija, K., Gold, H.K. and Virmani, R. (2006) Pathology of Drug-Eluting Stents in Humans: Delayed Healing and Late Thrombotic Risk. Journal of the American College of Cardiology, 48, 193-202. http://dx.doi.org/10.1016/j.jacc.2006.03.042

[5] Nakano, M., Otsuka, F., Yahagi, K., Sakakura, K., Kutys, R., Ladich, E.R., Finn, A.V., Kolodgie, F.D. and Virmani, R. (2013). Human Autopsy Study of Drug-Eluting Stents Restenosis: Histomorphological Predictors and Neointimal Characteristics. European Heart Journal, 34, 3304-3313. http://dx.doi.org/10.1093/eurheartj/eht241

[6] Hofma, S.H., van der Giessen, W.J., van Dalen, B.M., Lemos, P.A., McFadden, E.P., Sianos, G., Ligthart, J.M., van Essen, D., de Feyter, P.J. and Serruys, P.W. (2006) Indication of Long-Term Endothelial Dysfunction after SirolimusEluting Stent Implantation. European Heart Journal, 27, 166-170. http://dx.doi.org/10.1093/eurheartj/ehi571

[7] Shin, D.I., Kim, P.J., Seung, K.B., Kim, D.B., Kim, M.J., Chang, K., Lim, S.M., Jeon, D.S., Chung, W.S., Baek, S.H. and Lee, M.Y. (2007) Drug-Eluting Stent Implantation Could Be Associated with Long-Term Coronary Endothelial Dysfunction. International Heart Journal, 48, 553-567. http://dx.doi.org/10.1536/ihj.48.553

[8] Fuke, S., Maekawa, K., Kawamoto, K., Saito, H., Sato, T., Hioka, T. and Ohe, T. (2007) Impaired Endothelial Vasomotor Function after Sirolimus-Eluting Stent Implantation. Circulation Journal, 71, 220-225. http://dx.doi.org/10.1253/circj.71.220

[9] Hamilos, M.I., Ostojic, M., Beleslin, B., Sagic, D., Mangovski, L., Stojkovic, S., Nedeljkovic, M., Orlic, D., Milosavljevic, B., Topic, D., Karanovic, N., Wijns, W., NOBORI CORE Investigators (2008) Differential Effects of Drug-Eluting Stents on Local Endothelium-Dependent Coronary Vasomotion. Journal of the American College of Cardiology, 51, 2123-2129. http://dx.doi.org/10.1016/j.jacc.2007.12.059

[10] Sousa, J.E., Serruys, P.W. and Costa, M.A. (2003) New Frontiers in Cardiology: Drug-Eluting Stents: Part II. Circulation, 107, 2383-2389. http://dx.doi.org/10.1161/01.CIR.0000069331.67148.2F

[11] Carter, A.J., Laird, J.R., Farb, A., Kufs, W., Wortham, D.C. and Virmani, R. (1994) Morphologic Characteristics of Lesion Formation and Time Course of Smooth Muscle Cell Proliferation in a Porcine Proliferative Restenosis Model. Journal of the American College of Cardiology, 24, 1398-1405. http://dx.doi.org/10.1016/0735-1097(94)90126-0

[12] Kornowski, R., Hong, M.K., Tio, F.O., Bramwell, O., Wu, H. and Leon, M.B. (1998) In-Stent Restenosis: Contributions of Inflammatory Responses and Arterial Injury to Neointimal Hyperplasia. Journal of the American College of Cardiology, 31, 224-230. http://dx.doi.org/10.1016/S0735-1097(97)00450-6

[13] Vane, J.R. and Botting, R.M. (1995) Pharmacodynamic Profile of Prostacyclin. American Journal of Cardiology, 75, 3A-10A. http://dx.doi.org/10.1016/S0002-9149(99)80377-4

[14] Zucker, T.P., Bönisch, D., Hasse, A., Grosser, T., Weber, A.A. and Schrör, K. (1998) Tolerance Development to Antimitogenic Actions of Prostacyclin but Not of Prostaglandin E1 in Coronary Artery Smooth Muscle Cells. European Journal of Pharmacology, 345, 213-220. http://dx.doi.org/10.1016/S0014-2999(98)00022-3

[15] Voisard, R., Stemberger, A., Baur, R., Herter, T., Hähnel, I., Resch, A., Seliger, C., Hemmer, W., Hannekum, A., Hombach, V. and Alt, E. (2005) Triple-Coated Stents (Hirudin/Iloprost/Paclitaxel): An in Vitro Approach for Characterizing the Antiproliferative Potential of Each Individual Compound. International Journal of Cardiology, 102, 425433. http://dx.doi.org/10.1016/j.ijcard.2004.05.059

[16] Hata, A.N. and Breyer, R.M. (2004) Pharmacology and Signaling of Prostaglandin Receptors: Multiple Roles in Inflammation and Immune Modulation. Pharmacology and Therapeutics, 103, 147-166. http://dx.doi.org/10.1016/j.pharmthera.2004.06.003

[17] Della Bella, S., Molteni, M., Mocellin, C., Fumagalli, S., Bonara, P. and Scorza, R. (2001) Novel Mode of Action of Iloprost: In Vitro Down-Regulation of Endothelial Cell Adhesion Molecules. Prostaglandins and Other Lipid Mediators, 65, 73-83. http://dx.doi.org/10.1016/S0090-6980(01)00131-9

[18] Alt, E., Haehnel, I., Beilharz, C., Prietzel, K., Preter, D., Stemberger, A., Fliedner, T., Erhardt, W. and Schömig, A. (2000) Inhibition of Neointima Formation after Experimental Coronary Artery Stenting: A New Biodegradable Stent Coating Releasing Hirudin and the Prostacyclin Analogue Iloprost. Circulation, 101, 1453-1458.

http://dx.doi.org/10.1161/01.CIR.101.12.1453 
[19] McCormick, C., Jones, R.L., Kennedy, S. and Wadsworth, R.M. (2010) Activation of Prostanoid EP Receptors by Prostacyclin Analogues in Rabbit Iliac Artery: Implications for Anti-Restenotic Potential. European Journal of Pharmacology, 641, 160-167. http://dx.doi.org/10.1016/j.ejphar.2010.04.035

[20] Abramovitz, M., Adam, M., Boie, Y., Carrière, M., Denis, D., Godbout, C., Lamontagne, S., Rochette, C., Sawyer, N., Tremblay, N.M., Belley, M., Gallant, M., Dufresne, C., Gareau, Y., Ruel, R., Juteau, H., Labelle, M., Ouimet, N. and Metters, K.M. (2000) The Utilization of Recombinant Prostanoid Receptors to Determine the Affinities and Selectivities of Prostaglandins and Related Analogs. Biochimica et Biophysica Acta (BBA)-Molecular and Cell Biology of Lipids, 1483, 285-293. http://dx.doi.org/10.1016/s1388-1981(99)00164-x

[21] Coats, P., Kennedy, S., Pyne, S., Wainwright, C.L. and Wadsworth, R.M. (2008) Inhibition of Non-Ras Protein Farnesylation Reduces In-Stent Restenosis. Atherosclerosis, 197, 515-523. http://dx.doi.org/10.1016/j.atherosclerosis.2007.06.007

[22] Malik, N., Gunn, J., Holt, C.M., Shepherd, L., Francis, S.E., Newman, C.M., Crossman, D.C. and Cumberland, D.C. (1998) Intravascular Stents: A New Technique for Tissue Processing for Histology, Immunohistochemistry, and Transmission Electron Microscopy. Heart, 80, 509-516. http://dx.doi.org/10.1136/hrt.80.5.509

[23] Gunn, J., Arnold, N., Chan, K.H., Shepherd, L., Cumberland, D.C. and Crossman, D.C. (2002) Coronary Artery Stretch versus Deep Injury in the Development of In-Stent Neointima. Heart, 88, 401-405. http://dx.doi.org/10.1136/heart.88.4.401

[24] Levitt, M.A., Dryjski, M., Tluczek, J. and Bjornsson, T.D. (1991) Evaluation of a Prostacyclin Analog, Iloprost, and a Thromboxane $\mathrm{A}_{2}$ Receptor Antagonist, Daltroban, in Experimental Intimal Hyperplasia. Prostaglandins, 41, 1-6. http://dx.doi.org/10.1016/0090-6980(91)90099-2

[25] Banning, A., Brewer, L., Wendt, M., Groves, P.H., Cheadle, H., Penny, W.J. and Crawford, N. (1997) Local Delivery of Platelets with Encapsulated Iloprost to Balloon Injured Pig Carotid Arteries: Effect on Platelet Deposition and Neointima Formation. Thrombosis and Haemostasis, 77, 190-196.

[26] Isogaya, M., Yamada, N., Koike, H., Ueno, Y., Kumagai, H., Ochi, Y., Okazaki, S. and Nishio, S. (1995) Inhibition of Restenosis by Beraprost Sodium (a Prostaglandin I2 Analogue) in the Atherosclerotic Rabbit Artery after Angioplasty. Journal of Cardiovascular Pharmacology, 25, 947-952. http://dx.doi.org/10.1097/00005344-199506000-00013

[27] Schwartz, R.S., Chronos, N.A. and Virmani, R. (2004) Preclinical Restenosis Models and Drug-Eluting Stents: Still Important, Still Much to Learn. Journal of the American College of Cardiology, 44, 1373-1385. http://dx.doi.org/10.1016/j.jacc.2004.04.060

[28] Blindt, R., Bosserhoff, A.K., vom Dahl, J., Hanrath, P., Schror, K., Hohlfeld, T. and Meyer-Kirchrath, J. (2002) Activation of IP and $\mathrm{EP}_{3}$ Receptors Alters cAMP-Dependent Cell Migration. European Journal of Pharmacology, 444, 31-37. http://dx.doi.org/10.1016/S0014-2999(02)01607-2

[29] Murata, T., Ushikubi, F., Matsuoka, T., Hirata, M., Yamasaki, A., Sugimoto, Y., Ichikawa, A., Aze, Y., Tanaka, T., Yoshida, N., Ueno, A., Oh-ishi, S. and Narumiya, S. (1997) Altered Pain Perception and Inflammatory Response in Mice Lacking Prostacyclin Receptor. Nature, 388, 678-682. http://dx.doi.org/10.1038/41780

[30] Fetalvero, K.M., Martin, K.A. and Hwa, J. (2007) Cardioprotective Prostacyclin Signaling in Vascular Smooth Muscle. Prostaglandins and Other Lipid Mediators, 82, 109-118. http://dx.doi.org/10.1016/j.prostaglandins.2006.05.011

[31] Sirois, M.G., Simons, M., Kuter, D.J., Rosenberg, R.D. and Edelman, E.R. (1997) Rat Arterial Wall Retains Myointimal Hyperplastic Potential Long after Arterial Injury. Circulation, 96, 1291-1298. http://dx.doi.org/10.1161/01.CIR.96.4.1291

[32] Banai, S., Gertz, S.D., Gavish, L., Chorny, M., Perez, L.S., Lazarovichi, G., Ianculuvich, M., Hoffmann, M., Orlowski, M., Golomb, G. and Levitzki, A. (2004) Tyrphostin AGL-2043 Eluting Stent Reduces Neointima Formation in Porcine Coronary Arteries. Cardiovascular Research, 64, 165-171. http://dx.doi.org/10.1016/j.cardiores.2004.06.013

[33] Tamai, H., Igaki, K., Kyo, E., Kosuga, K., Kawashima, A., Matsui, S., Komori, H., Tsuji, T., Motohara, S. and Uehata, H. (2000) Initial and 6-Month Results of Biodegradable Poly-l-Lactic Acid Coronary Stents in Humans. Circulation, 102, 399-404. http://dx.doi.org/10.1161/01.CIR.102.4.399

[34] Lincoff, A.M., Furst, J.G., Ellis, S.G., Tuch, R.J. and Topol, E.J. (1997) Sustained Local Delivery of Dexamethasone by a Novel Intravascular Eluting Stent to Prevent Restenosis in the Porcine Coronary Injury Model. Journal of the American College of Cardiology, 29, 808-816. http://dx.doi.org/10.1016/S0735-1097(96)00584-0

[35] Mani, G., Feldman, M.D., Patel, D. and Agrawal, C.M. (2007) Coronary Stents: A Materials Perspective. Biomaterials, 28, 1689-1710. http://dx.doi.org/10.1016/j.biomaterials.2006.11.042

[36] van der Giessen, W.J., Lincoff, A.M., Schwartz, R.S., van Beusekom, H.M., Serruys, P.W., Holmes Jr., D.R. Ellis, S.G. and Topol, E.J. (1996) Marked Inflammatory Sequelae to Implantation of Biodegradable and Nonbiodegradable Polymers in Porcine Coronary Arteries. Circulation, 94, 1690-1697. http://dx.doi.org/10.1161/01.CIR.94.7.1690 
[37] Moses, J.W., Leon, M.B., Popma, J.J., Fitzgerald, P.J., Holmes, D.R., O’Shaughnessy, C., Caputo, R.P., Kereiakes, D.J., Williams, D.O., Teirstein, P.S., Jaeger, J.L. and Kuntz, R.E. (2003) Sirolimus-Eluting Stents versus Standard Stents in Patients with Stenosis in a Native Coronary Artery. The New England Journal of Medicine, 349, $1315-1323$. http://dx.doi.org/10.1056/NEJMoa035071

\section{Submit or recommend next manuscript to SCIRP and we will provide best service for you:}

Accepting pre-submission inquiries through Email, Facebook, Linkedin, Twitter, etc A wide selection of journals (inclusive of 9 subjects, more than 200 journals)

Providing a 24-hour high-quality service

User-friendly online submission system

Fair and swift peer-review system

Efficient typesetting and proofreading procedure

Display of the result of downloads and visits, as well as the number of cited articles

Maximum dissemination of your research work

Submit your manuscript at: http://papersubmission.scirp.org/ 